\title{
Molecular diagnosis of diarrheagenic Escherichia coli isolated from Psittaciformes of illegal wildlife trade ${ }^{1}$
}

\author{
Elisângela S. Lopes ${ }^{2 *}$, William C. Maciel², \\ Pedro Henrique Q.S. Medeiros ${ }^{3}$, Mariana D. Bona ${ }^{3}$, Alexandre H. Bindá ${ }^{3}$, \\ Suzan V.G. Lima², Fernanda C. Gaio ${ }^{2}$ and Régis S.C. Teixeira ${ }^{2}$
}

\begin{abstract}
Lopes E.S., Maciel W.C., Medeiros P.H.Q.S., Bona M.D., Bindá A.H., Lima S.V.G., Gaio F.C. \& Teixeira R.S.C. 2018. Molecular diagnosis of diarrheagenic Escherichia coli isolated from Psittaciformes of illegal wildlife trade. Pesquisa Veterinária Brasileira 38(4):762-766. Laboratório de Estudos Ornitológicos, Faculdade de Veterinária, Universidade Estadual do Ceará, Campus do Itaperi, Av. Silas Munguba 1700, Fortaleza, CE 60714-903, Brazil. E-mail: elisangeladesouzalopes@hotmail.com

Diarrheagenic Escherichia coli (DEC) are considered one of the major causes of human diarrhea in developing countries. Some studies have pointed wild birds as important reservoirs for these pathogens. However, scarce species from the Psittaciformes order have been investigated. This study aimed to evaluate the presence of DEC strains in Psittaciformes from illegal wildlife trade. A total of $78 \mathrm{E}$. coli strains isolated from cloacal swab samples of 167 Psittaciformes in the Ceará State, Brazil, were evaluated regarding the presence of the following DEC virulence genes by polymerase chain reaction (PCR): eaeA and $b f p A$ genes (Enteropathogenic E. coli - EPEC); stx 1 and stx2 (Shiga toxin-producing E. coli - STEC); est $\mathrm{A}$ and eltB (Enterotoxigenic E. coli - ETEC); ipaH (Enteroinvasive E. coli - EIEC); aatA and aaiC (Enteroaggregative E. coli - EAEC). Positive strains for eaeA and $b f p A$ genes were considered typical EPEC, while strain positive exclusively for the eaeA gene were classified as atypical EPEC. The eaeA gene was identified in 20 E. coli strains and $b f p A$ in 22 isolates. In addition, 11 and 9 belonged to tEPEC and aEPEC, respectively. No strain was positive for stx 1 or stx2. A total of $47(60.3 \%)$ strains and a total of 136 birds $(81.4 \%)$ were negative for the remaining DEC pathotypes investigated. In conclusion, psittacine from illegal wildlife trade in Ceará State, Brazil, presented a relevant prevalence of typical and atypical EPEC, potentially playing a role as reservoirs of DEC strains in the environment. Thus, proper control measures must be adopted to block the spread of these pathogens.
\end{abstract}

INDEX TERMS: EPEC, Escherichia coli, Psittaciformes, wildlife traffic, birds, bacterioses.

\begin{abstract}
RESUMO.- [Diagnóstico molecular de Escherichia coli diarreiogênicas isoladas de Psittaciformes do tráfico ilegal de animais silvestres.] Escherichia coli diarreiogênicas (DEC) são consideradas uma das causas mais importantes de diarreia em países em desenvolvimento. Alguns estudos têm apontado
\end{abstract}

\footnotetext{
${ }^{1}$ Received on April 28, 2017.

Accepted for publication on September 28, 2017.

2 Programa de Pós-Graduação em Ciências Veterinárias (PPGCV), Laboratório de Estudos Ornitológicos (Labeo), Faculdade de Veterinária, Universidade Estadual do Ceará (UECE), Campus do Itaperi, Av. Silas Munguba 1700, Fortaleza, CE 60714-903, Brazil. *Corresponding author: elisangeladesouzalopes@hotmail.com

${ }^{3}$ Laboratório de Toxinologia Molecular, Escola de Medicina, Universidade Federal do Ceará (UFC), Campus do Porangabussu, Rua Alexandre Baraúna 949, Rodolfo Teófilo, Fortaleza, CE 60430-160.
}

aves silvestres como importantes reservatórios destes patógenos, entretanto, poucas espécies da ordem Psittaciformes têm sido investigada. 0 objetivo deste estudo foi analisar a presença de cepas de E. coli diarreiogênicas em Psittaciformes do tráfico de animais silvestres. Um total de 78 amostras de $E$. coli isoladas de suabes cloacais provenientes de 167 de Psittaciformes do Ceará, Brasil, foram avaliadas quanto a presença dos seguintes genes de virulência DEC por meio de reação em cadeia de polimerase (PCR): eaeA e bfpA (E. coli Enteropatogênica - EPEC); stx 1 e stx 2 (E. coli produtora de Shiga - STEC); estA e eltB (E.coliEnterotoxigênica-ETEC);ipaH(E.coliEnteroinvasiva-EIEC); aatA e aaiC (E. coli Enteroagregativa - EAEC). As cepas positivas para os genes eaeA e $b f p \mathrm{~A}$ foram consideradas EPEC típicas, enquanto que as positivas exclusivamente para o gene eaeA foram classificadas como EPEC atípicas. $\mathrm{O}$ gene eaeA foi 
identificado em 20 cepas de E. coli e o gene bfpA em 22 dos isolados. Adicionalmente, 11 e 9 cepas foram classificadas como EPEC típicas e atípicas, respectivamente. Nenhuma cepa foi positiva para os genes stx 1 e stx 2 Um total de 47 cepas $(60,3 \%)$ e um total de 136 aves $(81,4 \%)$ foram negativas para os demais patotipos DEC pesquisados. Em conclusão, psitacídeos provenientes do tráfico de aves silvestres do estado do Ceará, Brasil, apresentaram relevante prevalência de EPEC típicas e atípicas, potencialmente participando como reservatórios de cepas DEC no ambiente. Portanto, medidas de controle devem ser adotadas para inibir a disseminação destes patógenos.

TERMOS DE INDEXAÇÃO: EPEC, Escherichia coli, Psittaciformes, tráfico de animais silvestres, aves, bacterioses.

\section{INTRODUCTION}

Recent studies have observed the isolation of Escherichia coli from captive, traded and free-living psittacine (Saidenberg et al. 2012a, 2012b, Hidasi et al. 2013). However, there are scarce reports on virulence characterization of these strains. Currently, pathogenic $E$. coli is classified as intestinal pathogenic (or diarrheagenic E. coli - DEC) and extra-intestinal pathogenic E. coli (ExPEC) (Russo \& Johnson 2000). DEC are further classified as enteropathogenic (EPEC), enterohemorragic (EHEC), enterotoxigenic (ETEC), enteroinvasive (EIEC), enteroaggregative (EAEC) and diffusely adherent (DAEC) E. coli (Croxen et al. 2013).

EPEC are the most prevalent DEC in psittacine (Saidenberg et al. 2012a). These strains are characterized by an "attaching and effacing" lesion (A/E), marked by the presence of eaeA gene (Ochoa \& Contreras 2011). Moreover, EPEC are divided in atypical (aEPEC) and typical (tEPEC). Only tEPEC contains a virulence plasmid known as EPEC adherence factor (EAF), which harbors the bundle-forming pili (BFP) gene. This virulence factor provides adhesion of the bacterium to the host cell, which can be observed up to three hours after contact. However, aEPEC does not possess this plasmid (Trabulsi et al. 2002, Donnenberg \& Finlay 2013).

tEPEC are classically responsible for most severe diarrhea in children less than five years of age (Croxen et al. 2013), while aEPEC are found more frequently, regardless of diarrhea (Beutin et al. 2003, Carvalho et al. 2003, Nakazato et al. 2004, Aidar-Ugrinovich et al.2007). Although there are some reports of tEPEC identification in psittacine (Schremmer et al. 1999), this pathotype is known to be rarely isolated from animals (Trabulsi et al. 2002, Carvalho et al. 2003, Nakazato et al. 2004). On the other hand, farm, pet and wild animals are recognized as possible reservoirs and sources of aEPEC infection for humans (Carvalho et al. 2003, Nakazato et al. 2004, Krause et al. 2005, Ishii et al. 2007, Almeida et al. 2012).

Other DECs of human clinical importance have also been investigated in psittacine, such as EHEC and EAEC, which were identified in captive birds (Marietto-Gonçalves et al. 2011). EHEC are associated with hemorrhagic colitis and uremic hemolytic syndrome, while EAEC is highly prevalent in children and adults (Ferens \& Hovde 2011), in which is responsible for acute diarrhea outbreaks in developed and developing countries (Steffen et al. 2015).

The demand for breeding psittacine has increased in recent years and this growth continues to be a tendency.
This interest leads to the acquisition of these birds in legal and illegal wildlife trade. In this manner, the contact of man and psittacine, as occurs in domestic animals, is increasingly closer, generating the possibility of mutual transmission of microorganisms. Considering the health risk that pathogenic members of the Enterobacteriaceae family pose, researches have raised concern on the dissemination of these pathogens in the environment in which psittacine are maintained (Lopes et al. 2016). In addition, considering the importance of these pathogens for human health and the paucity of studies about these microorganisms in psittacine, the objective of this study was to evaluate the presence of DEC strains in Psittaciformes from illegal wildlife trade in Fortaleza, Brazil.

\section{MATERIALS AND METHODS}

Bacterial strains. A total of 78 Escherichia coli strains isolated by Lopes et al. (2015) from 167 clinically healthy psittacine, seized from illegal wildlife trade in the wildlife rehabilitation center located in the city of Fortaleza, Brazil, was collected from July to November 2013. Each bird was submitted to a single collection of individual cloacal swab and one representative colony was selected per bird. To avoid repetitions, all birds within the same pen were sampled in the same visit and different pens were collected in different periods. Strains maintained in nutrient agar were reactivated in BHI broth and plated in MacConkey for $24 \mathrm{~h}$ at $37^{\circ} \mathrm{C}$.

DNA extraction. From each plate, two to three colonies were collected and placed in tubes containing $1 \mathrm{~mL}$ of $0.5 \%$ Triton X-100, which were vortexed for $15 \mathrm{~s}$ and boiled for $20 \mathrm{~min}$ at $94^{\circ} \mathrm{C}$. Tubes were then centrifuged at $10.000 \mathrm{rpm}$ for $10 \mathrm{~min}$. Supernatant containing DNA was quantified and qualified by spectrophotometry using NanoDrop Spectrophotometer 2000 (Thermo Scientific, Wilmington, USA).

Molecular diagnosis of DEC. DNA samples were submitted to uniplex polymerase chain reactions (PCR) for the diagnosis of DEC from $E$. coli strains isolated from cloacal swabs. The presence of eight genes of virulence genes from five pathotypes was evaluated as follows: genes stx1 (348pb) and stx2 (584pb) for the identification of Shiga-Toxin producing E. coli (STEC); eltB (508pb) and estA (147pb) for enterotoxigenic E. coli (ETEC); eaeA (881 pb) and bfpA (300 pb) for enteropathogenic E. coli (EPEC); ipa $\mathrm{H}(483 \mathrm{pb}$ ) for enteroinvasive E. coli (EIEC); aatA ( $630 \mathrm{pb})$ and aaiC $(215 \mathrm{pb})$ for enteroaggregative E. coli (EAEC) (Taniuchi et al. 2012)(Table1). EPEC strains are classified as typical when possessing eaeA and bfpA genes, without stx; and as atypical if only the eaeA gene is found (Donnenberg \& Finlay 2013). Strains EAEC 042, EHEC 0157:H7, EIEC 0124, EPEC 2348/69 and ETEC H10407 were used as positive controls for the reactions. PCR was performed using GoTaqGreen kit (Promega) and primers at $0.2 \mathrm{uM}$ in MyCycler Thermal Cycler (Biorad, CA, USA), with the following protocol: $95^{\circ} \mathrm{C}$ for $15 \mathrm{~min} ; 40$ cycles of $95^{\circ} \mathrm{C}$ for $30 \mathrm{~s}, 57^{\circ} \mathrm{C}$ for $30 \mathrm{~s}$ and $72^{\circ} \mathrm{C}$ for $1 \mathrm{~min}$; followed by $72^{\circ} \mathrm{C}$ for $10 \mathrm{~min}$. Amplified products were submitted to $2 \%$ ethidium bromide stained agarose gel electrophoresis and photo-documented by the transilluminator ChemicDoc XRS System (Biorad, CA, USA).

\section{RESULTS}

From the total of 78 Escherichia coli strains isolated from psittacine of illegal wildlife trade, only eaeA and $b f p A$ genes were detected. The prevalence rates of these genes in the investigated psittacine were $12.0 \%(20 / 167)$ and 13.2 (22/167) for eaeA and bfpA respectively. Considering 
eaeA and $b f p A$ genes, $6.6 \%(11 / 167)$ of birds were positive for strains as tEPEC, while $5.4 \%(9 / 167)$ were classified as aEPEC. In addition, $60.3 \%$ (47/78) of isolated bacteria and 81.4\% (136/167) of evaluated psittacine did not harbor any of the virulence genes used to diagnose EPEC, EIEC, EHEC, EAEC or ETEC. Furthermore, tEPEC prevalence within species was: 4/66 Amazona aestiva (6.1\%), 3/13 Amazona amazonica $(23.1 \%)$ and 4/67 Eupsitulla cactorum (6.0\%) (Table 2).

Table 1. The primers used for detection of the various genes by PCR, amplicon size

\begin{tabular}{|c|c|c|c|}
\hline Genes & $\begin{array}{l}\text { Description of } \\
\text { the target genes }\end{array}$ & Oligonucleotide primer pairs (5'-3') & $\begin{array}{l}\text { Amplicon } \\
\text { (pb) }\end{array}$ \\
\hline Stx 1 & STEC & $\begin{array}{l}\text { ACTTCTCGACTGCAAAGACGTATG } \\
\text { ACAAATTATCCCCTGAGCCACTATC }\end{array}$ & 348 \\
\hline Stx2 & STEC & $\begin{array}{l}\text { GGCACTGTCTGAAACTGCTCC } \\
\text { TCGCCAGTTATCTGACATTCTG }\end{array}$ & 584 \\
\hline eltB & ETEC & $\begin{array}{c}\text { TTCCCACCGGATCACCAA } \\
\text { CAACCTTGTGGTGCATGATGA }\end{array}$ & 508 \\
\hline est $\mathrm{A}$ & ETEC & $\begin{array}{l}\text { TTCACCTTTCGCTCAGGATG } \\
\text { AGCACCCGGTACAAGCAG }\end{array}$ & 147 \\
\hline eaeA & EPEC & $\begin{array}{l}\text { GTAAAGTCCGTTACCCCAACCTG } \\
\text { CAAAGCGCACAAGACTACCA }\end{array}$ & 881 \\
\hline$b f p \mathrm{~A}$ & EPEC & $\begin{array}{l}\text { GGAAGTCAAATTCATGGGGG } \\
\text { GGAATCAGACGCAGACTGGT }\end{array}$ & 300 \\
\hline ipa $\mathrm{H}$ & EIEC & $\begin{array}{l}\text { CCTTTTCCGCGTTCCTTGA } \\
\text { CGGAATCCGGAGGTATTGC }\end{array}$ & 483 \\
\hline aatA & EAEC & $\begin{array}{l}\text { CTGGCGAAAGACTGTATCAT } \\
\text { TTTTGCTTCATAAGCCGATAGA }\end{array}$ & 630 \\
\hline aaiC & EAEC & $\begin{array}{l}\text { ATTGTCCTCAGGCATTTCAC } \\
\text { ACGACACCCCTGATAAACAA }\end{array}$ & 215 \\
\hline
\end{tabular}

Adapted from Taniuchi et al. (2012).

\section{DISCUSSION}

This study identified important DEC virulence genes (eaeA and $b f p A$ ) in Escherichia coli strains isolated from psittacine of illegal wildlife trade, which are important to diagnose the EPEC pathotype. Although these bacteria are recognized as important human pathogens (Peréz et al. 2010, Gomes et al. 2016), aEPEC have also been associated with increasing morbidity and mortality of Budgerigars (Seeley et al. 2014).

The detected percentages of $\mathrm{EPEC}$ and aEPEC in this research were higher than results found in most reports involving psittacine. Studies about psittacine in free-life, zoos, rescue centers and commercial breeders present prevalence rates of up to $6.5 \%$ for tEPEC and $2.3 \%$ for aEPEC in strains isolated from cloacal swabs (Schremmer et al. 1999, Saidenberg et al. 2012a, 2012b, 2015, Marietto-Gonçalves et al. 2011).

The majority of E. coli strains isolated in this study (60.3\%) did not harbor any of the genes analyzed and, therefore are not identified as any of the DEC investigated in this study harmful for human health (EPEC, EIEC, EHEC, EAEC, ETEC). Considering that reports of EPEC isolated from psittacine are scarce, the other DEC pathotypes appear to be even harder to identify. Marietto-Gonçalves et al. (2011) surveying for DEC in 86 captive psittacine observed strains of STEC and EAEC, in addition to EPEC. Koochakzadeh et al. (2015) investigated st 1 , stx 2 and eaeA genes in $30 \mathrm{E}$. coli strains from psittacine of pet shops in Iran. However, none of the strains presented these genes. EPEC (eae) and STEC (stx2) genes have been isolated in a study performed by Gioia-Di Chiacchio et al. (2016) with cockatiels and budgerigars, which are common pet psittacine.

Studies with other avian species also showed that the DEC genes analyzed here may be detected elsewhere. The study of Chandran \& Mazumder (2014) reported an elevated rate of positive samples for DEC diagnosing genes. From a total of 412 samples collected from captivity-bred birds of 15 different species, 63 isolates harboring the stx gene were detected.

Table 2. Absolute (n) and relative (\%) frequencies of Escherichia coli pathotypes isolated from psittacine of illegal wildlife trade in the state of Ceará, Brazil

\begin{tabular}{|c|c|c|c|c|c|c|}
\hline \multirow{2}{*}{ Sample source } & \multirow{2}{*}{$\begin{array}{c}\text { Number of } \\
\text { investigated birds }\end{array}$} & \multirow{2}{*}{$\begin{array}{l}\text { Absolute and relative } \\
\text { frequencies of } E \text {. coli } \\
\text { per avian species }\end{array}$} & \multicolumn{2}{|c|}{ EPEC } & \multirow{2}{*}{$\begin{array}{l}\text { E. coli containing } \\
\text { only bfpA }\end{array}$} & \multirow{2}{*}{$\begin{array}{c}\text { Birds negative for } \\
\text { the investigated } \\
\text { genes }\end{array}$} \\
\hline & & & Typical & Atypical & & \\
\hline & & & $n(\%)$ & $\mathrm{n}(\%)$ & $\mathrm{n}(\%)$ & n (\%) \\
\hline Amazona amazonica & 13 & $8(61.5)$ & $3(23.1)$ & $2(15.4)$ & $1(7.7)$ & $7(53.8)$ \\
\hline Eupsitulla cactorum & 67 & $19(28.4)$ & $4(6.0)$ & $4(6.0)$ & $4(6.0)$ & $55(82.1)$ \\
\hline Brotogeris chiriri & 2 & $2(100.0)$ & - & $1(50.0)$ & - & $1(50.0)$ \\
\hline Ara ararauna & 7 & $4(57.1)$ & - & - & - & $7(100.0)$ \\
\hline Anodorhynchus hyacinthinus & 3 & $1(33.3)$ & - & - & - & $3(100.0)$ \\
\hline Ara severus & 1 & $1(100.0)$ & - & - & - & $1(100.0)$ \\
\hline Amazonas farinosa & 1 & - & - & - & - & $1(100.0)$ \\
\hline Ara macao & 2 & - & - & - & - & $2(100.0)$ \\
\hline
\end{tabular}

The following genes were negative in all samples: aaiC, st $x 1$, stx2, elt $\mathrm{B}$, est $\mathrm{A}, i p a \mathrm{H}$, aatA. 
However, ETEC and EIEC related genes were not identified. In addition, Saviolli et al. (2016) looked for the genes eaeA, stx 1 e stx 2 in free-living fragatas (Fregata magnificens) and did not detect EPEC or STEC genes.

The detection of eaeA and $b f p A$ genes in some of the bacterial strains isolated from psittacine suggests that these birds might have a contamination source for these pathogenic strains. Studies with psittacine in captivity or from illegal wildlife trade, in which tEPEC were identified, show that the likely source of contamination may have anthropozoonotic character, considering the poor environmental conditions of these places (Saidenberg et al. 2012b).

Illegal wildlife trade might have influenced the findings here described, as it contributes to a closer contact between wild and domestic species, in addition to humans (Kruse et al. 2004). Trafficked wild birds are potential reservoirs of important agents of human health (Matias et al. 2016). Thus, measures, such as quarantine, are essential for avoiding the spread of strains with zoonotic potential. Marietto-Gonçalves et al. (2010) explained that the monitoring of Gram-negative bacteria in the enteric microbiota of Psittaciformes is a procedure that must be included in the routine of private breeders, zoos, veterinary hospitals and main programs that aim to reintroduce captive birds back to the wild. Such sanitary care measures are important not only because $E$. coli is not a member of the normal microbiota of these birds, but also due to the risk of dissemination of these pathogens to the wild environment, contributing for the epidemiologic chain of a variety of enteric diseases for humans and other animals.

\section{CONCLUSIONS}

The findings suggest that psittacine from illegal wildlife trade in Ceará, Brazil, present important prevalence of typical and atypical EPEC. Thus we suggest that Escherichia coli isolates from these birds must be further investigated, considering that clinically healthy wild birds might harbor bacterial strains that present virulence factors relevant for human and animal health.

A possible explanation for the isolation of pathogens in this study is the close contact between wild birds and domestic species, or even directly with humans, that occurs in illegal wildlife trade or captivity. Therefore the importance of adequate sanitary conditions in wildlife rehabilitation centers is reinforced, considering that the absence of effective prophylactic measures and disease control may favor dissemination.

In addition, these birds may transmit pathogens to other animals in nature, following reintroduction into the wild, or even into private environment of legal breeders, maintaining the cycle of transmission of these microorganisms.

\section{REFERENCES}

Aidar-Ugrinovich L., Blanco J., Blanco M., Blanco J.E., Leomil L., Dahbi G., Mora A., Onuma D.L., Silveira W.D. \& Pestana A.F.P. 2007. Serotypes, virulence genes, and intimin types of Shiga toxinproducing Escherichia coli (STEC) and enteropathogenic E. coli (EPEC) isolated from calves in São Paulo, Brazil. Int. J. Food Microbiol. 115(3):297-306. http://dx.doi.org/10.1016/j. ijfoodmicro.2006.10.046. PMid:17292501.

Almeida P.M., Arais L.R., Andrade J.R., Prado E.H., Irino K. \& Cerqueira A.M. 2012. Characterization of atypical Enteropathogenic Escherichia coli
(aEPEC) isolated from dogs. Vet. Microbiol. 158(3/4):420-424. http:// dx.doi.org/10.1016/j.vetmic.2012.02.021. PMid:22421111.

Beutin L., Marchés O., Bettelheim K.A., Gleier K., Zimmermann S., Schmidt H. \& Oswald E. 2003. Hep-2 cell adherence, actin aggregation, and intimin types of attaching and effacing Escherichia coli strains isolated from healthy infants in Germany and Australia. Infect. Immun. 71(7):3995-4002. http:// dx.doi.org/10.1128/IAI.71.7.3995-4002.2003. PMid:12819087.

Carvalho V.M., Gyles C.L., Ziebell K., Ribeiro M.A., Catão-Dias J.L., Sinhorini I.L., Otman J., Keller R., Trabulsi L.R. \& Pestana de Castro A.F. 2003 Characterization of monkey enteropathogenic Escherichia coli (EPEC) and human typical and atypical EPEC serotype isolates from neotropical no nhuman primates. J. Clin. Microbiol. 41(3):1225-1234. http://dx.doi. org/10.1128/JCM.41.3.1225-1234.2003. PMid:12624055.

Chandran A. \& Mazumder A. 2014. Occurrence of diarrheagenic virulence genes and genetic diversity in Escherichia coli isolates from fecal material of various avian hosts in British Columbia, Canada. Appl. Environ. Microbiol. 80(6):1933-1940. http://dx.doi.org/10.1128/AEM.03949-13. PMid:24441159.

Croxen M.A., Law R.J., Scholz R., Keeney K.M., Wlodarska M. \& Finlay B.B. 2013. Recent advances in understanding enteric pathogenic Escherichia coli. Clin. Microbiol. Rev. 26(4):822-880. http://dx.doi.org/10.1128/ CMR.00022-13. PMid:24092857.

Donnenberg M.S. \& Finlay B.B. 2013. Combating enteropathogenic Escherichia coli (EPEC) infections: the way forward. Trends Microbiol. 21(7):317-319. http://dx.doi.org/10.1016/j.tim.2013.05.003. PMid:23815982.

Ferens W.A. \& Hovde C.J. 2011. Escherichia coli 0157:H7: animal reservoir and sources of human infection. Foodborne Pathog. Dis. 8(4):465-487. http://dx.doi.org/10.1089/fpd.2010.0673. PMid:21117940.

Gioia-Di Chiacchio R.M., Cunha M.P., Sturn R.M., Moreno L.Z., Moreno A.M., Pereira C.B., Martins F.H., Franzolin M.R., Piazza R.M. \& Knöbl T. 2016. Shiga toxin-producing Escherichia coli (STEC): zoonotic risks associated with psittacine pet birds in home environments. Vet. Microbiol. 184:2730. http://dx.doi.org/10.1016/j.vetmic.2016.01.004. PMid:26854341.

Gomes T.A., Elias W.P., Scaletsky I.C., Guth B.E., Rodrigues J.F., Piazza R.M., Ferreira L.C. \& Martinez M.B. 2016. Diarrheagenic Escherichia coli. Braz. J. Microbiol. 47(Suppl. 1):3-30.http://dx.doi.org/10.1016/j.bjm.2016.10.015. PMid:27866935.

Hidasi H.W., Hidasi Neto J., Moraes D.M., Linhares G.F., Jayme V.S. \& Andrade M.A. 2013. Enterobacterial detection and Escherichia coli antimicrobial resistance in parrots seized from the illegal wildlife trade. J.Zoo Wildl. Med. 44(1):1-7. http://dx.doi.org/10.1638/1042-7260-44.1.1. PMid:23505696.

Ishii S., Meyer K.P. \& Sadowsky M.J. 2007. Relationship between phylogenetic groups, genotypic clusters, and virulence gene profiles of Escherichia coli strains from diverse human and animal sources. Appl. Environ. Microbiol. 73(18):5703-5710. http://dx.doi.org/10.1128/AEM.0027507. PMid:17644637.

Koochakzadeh A., Badouei A.M., Salehi Z.T., Aghasharif S., Soltani M. \& Ehsan M.R. 2015. Prevalence of Shiga toxin-producing and enteropathogenic Escherichia coli in wild and pet birds in Iran. Braz. J. Poult. Sci. 17(4):445-450.

Krause G., Zimmermann S. \& Beutin L. 2005. Investigation of domestic animals and pets as a reservoir for intimin-(eae) gene positive Escherichia coli types. Vet. Microbiol. 106(1/2):87-95. http://dx.doi.org/10.1016/j. vetmic.2004.11.012. PMid:15737477.

Kruse H., Kirkemo A.M. \& Handeland K. 2004. Wildlife as source of zoonotic infections. Emerg. Infect. Dis. 10(12):2067-2072. http://dx.doi.org/10.3201/ eid1012.040707. PMid:15663840.

Lopes E.S., Maciel W.C., Albuquerque A.H., Nishi D.M., Bezerra W.G.A., Horn R.V., Lima B.P., Marietto-Gonçalves G.A. \& Teixeira R.S.C. 2015. Prevalence and Antimicrobial resistance profile of Enterobacteria isolated from psittaciformes of illegal wildlife trade. Acta Scient. Vet. 43(1313):1-9.

Lopes E.S., Maciel W.C., Teixeira R.S.C., Albuquerque A.H., Horn R.V., Nishi D.M., Bezerra W.G.A. \& Santos I.C.L. 2016. Isolamento de Salmonella spp. e 
Escherichia colide psittaciformes: relevância em saúde pública. Arqs Inst. Biológico, São Paulo, 83:1-10.

Marietto-Gonçalves G.A., Almeida S.M. \& Rodrigues J. 2011. Presence of a human diarrheagenic Escherichia coli clone in captivity kept Psittacidae. Open Microbiol. J. 5(1):72-75. http://dx.doi.org/10.2174/18742858011 05010072. PMid:21792380.

Marietto-Gonçalves G.A., Almeida S.M., Lima E.T., Okamoto A.S., Pinczowski P. \& Andreatti Filho R.L. 2010. Isolation of Salmonella enterica Serovar Enteritidis in Blue-Fronted Amazon Parrot (Amazona aestiva). Avian Dis. 54(1):151-155. http://dx.doi.org/10.1637/8906-043009-Case.1. PMid:20408416.

Matias C.A., Pereira I.A., Araújo Mdos.S., Santos A.F., Lopes R.P., Christakis S., Rodrigues D.P. \& Siciliano S. 2016. Characteristics of Salmonella spp. isolated from wild birds confiscated in illegal trade markets, Rio de Janeiro, Brazil. Biomed. Res. Int. 2016:3416864. http://dx.doi.org/10.1155/2016/3416864. PMid:26881216.

Nakazato G., Gyles C., Ziebell K., Keller R., Trabulsi L.R., Gomes T.A., Irino K., Silveira W.D. \& Castro A.F.P. 2004. Attaching and effacing Escherichia coli isolated from dogs in Brazil: characteristics and serotypic relationship to human enteropathogenic E. coli (EPEC). Vet. Microbiol. 101(4):269-277. http://dx.doi.org/10.1016/j.vetmic.2004.04.009. PMid:15262000.

Ochoa T.J. \& Contreras C.A. 2011. Enteropathogenic Escherichia coli infection in children. Curr. Opin. Infect. Dis. 24(5):478-483. http://dx.doi.org/10.1097/ QC0.0b013e32834a8b8b. PMid:21857511.

Pérez C., Gómez-Duarte O.G. \& Arias M.L. 2010. Diarrheagenic Escherichia coli in children from Costa Rica. Am. J. Trop. Med. Hyg. 83(2):292-297. http:// dx.doi.org/10.4269/ajtmh.2010.09-0412. PMid:20682870.

Russo T.A. \& Johnson J.R. 2000. Proposal for a new inclusive designation for extraintestinal pathogenic isolates of Escherichia coli: ExPEC. J. Infect. Dis. 181(5):1753-1754. http://dx.doi.org/10.1086/315418. PMid:10823778.

Saidenberg A.B., Guedes N.M.R., Seixas G.H.F., Allgayer M.C., Assis E.P., Silveira L.F., Melville P.A. \& Benites N.R. 2012a. A survey for Escherichia coli virulence factors in asymptomatic free-ranging parrots. ISRN Dentistry 2012:984813. PMid:23738135.
Saidenberg A.B., Teixeira R.H.F., Guedes N.M.R., Allgayer M.C., Melville P.A. \& Benites N.R. 2012b. Molecular detection of enteropathogenic Escherichia coli in asymptomatic captive psittacines. Pesq. Vet. Bras. 32(9):922-926. http://dx.doi.org/10.1590/S0100-736X2012000900017.

Saidenberg A.B.S., Zuniga E., Melville P.A., Salaberry S. \& Benites N.R. 2015. Health-screening protocols for vinaceous amazons (Amazona vinacea) in a reintroduction project. J. Zoo Wildl. Med. 46(4):704-712. http://dx.doi. org/10.1638/2013-0152.1. PMid:26667526.

Saviolli J.Y., Cunha M.P.V., Guerra M.F.L., Irino K., Catão-Dias J.L. \& Carvalho V.M. 2016. Free-ranging frigates (Fregata magnificens) of the Southeast Coast of Brazil harbor extraintestinal pathogenic Escherichia coli resistant to antimicrobials. PlosOne 4(2):1-14. https://doi.org/10.1371/journal. pone. 0148624 .

Schremmer C., Lohr J.E., Wastlhuber U., Kosters J., Ravelshofer K., Steinruck H. \& Wieler L.H. 1999. Enteropatogenic Escherichia coli in Psittaciformes. Avian Pathol. 28(4):349-354. http://dx.doi.org/10.1080/03079459994605. PMid:26905491.

Seeley K.E., Baitchman E., Bartlett S., DebRoy C. \& Garner M.M. 2014. Investigation and control of an attaching and effacing Escherichia coli outbreak in a colony of captive budgerigars (Melopsittacus undulatus). J. Zoo Wildl. Med. 45(4):875-882. http://dx.doi.org/10.1638/2012-0281.1. PMid:25632676.

Steffen R., Hill D.R. \& DuPont H.L. 2015. Traveler's diarrhea: a clinical review. J. Am. Med. Assoc. 313(1):71-80. http://dx.doi.org/10.1001/ jama.2014.17006. PMid:25562268.

Taniuchi M., Walters C.C., Gratz J., Maro A., Kumburu H., Serichantalergs O., Sethabutr O., Bodhidatta L., Kibiki G., Toney D.M., Berkeley L., Nataro J.P. \& Houpt E.R. 2012. Development of a multiplex polymerase chain reaction assay for diarrheagenic Escherichia coli and Shigella spp. and its evaluation on colonies, culture broths, and stool. Diagn. Microbiol. Infect. Dis. 73(2):121-128. http://dx.doi.org/10.1016/j.diagmicrobio.2012.03.008. PMid:22541788.

Trabulsi L.R., Keller R. \& Gomes T.A.T. 2002. Typical and atypical enteropathogenic Escherichia coli. Emerg. Infect. Dis. 8(5):508-6. http://dx.doi.org/10.3201/ eid0805.010385. PMid:11996687. 